\title{
THE EFFECTS OF PLEURAL EFFUSION ON RESPIRATION AND CIRCULATION IN MAN
}

\author{
By MARK D. ALTSCHULE AND NORMAN ZAMCHECK \\ (From the Medical Service and Medical Research Laboratories, Beth Israel Hospital, and the \\ Department of Medicine, Harvard Medical School, Boston)
}

(Received for publication August 17, 1943)

\section{INTRODUCTION}

Pleural effusion commonly complicates many diseases and its manifestations may alter or overshadow those of the underlying disorder. The severity of the respiratory symptoms associated with pleural fluid varies markedly from patient to patient and depends to some extent on the nature of the disease causing the effusion. The present study was made in an effort to gain a better understanding of the mechanisms responsible for the occurrence of and variations in respiratory manifestations in patients with pleural effusions. The effects of pleural effusion were estimated by comparing respiratory and circulatory dynamics before and after thoracentesis. The respiratory dynamics could be studied only in patients who were slightly or moderately dyspneic; accordingly, the findings of this study may not completely explain the symptoms occurring in patients with extreme degrees of discomfort.

\section{MATERIAL AND METHODS}

Eight patients, ranging in age from 22 to 72 years, were studied; 3 were males (Patients 1, 2, and 5). Patients 5, 6,7 , and 8 had congestive failure due to coronary artery sclerosis, associated in Patient 6 with thyrotoxicosis. Patient 4 had a pulmonary neoplasm. Patient 3 had a tuberculous effusion with no demonstrable parenchymal lesion. No definite diagnosis was made in Patients 1 and 2, although congestive failure, neoplasm, tuberculosis, and pneumonia were all ruled out; Patient 2 had a moderate degree of senile emphysema.

All studies were made with the patients sitting in bed with the trunk at an angle of $45^{\circ}$ to $80^{\circ}$ with the horizontal; approximately the same angle was used in all studies on a given subject. Measurements of the cardiac output were made with the patients in a basal state, 15 hours after the last meal. All other studies were made at least 2 hours after the patient's last meal and after he had rested in bed for at least forty minutes. The method of Starr and Gamble (1) was used for estimating the cardiac output, oxygen consumption, and respiratory tidal, and minute volumes being measured simultaneously. The functional residual air was determined by Christie's method (2), slightly modified (3), oxygen consumption and respiratory tidal, and minute volumes being measured simultaneously; reserve and complemental air volumes were measured separately. The venous pressure was measured by the direct method of Moritz and von Tabora (4), the circulation time by the decholin method (5), the arterial pressure by the auscultatory method using a standard cuff, and the arterial blood gas content by the method of Van Slyke and Neill (6), using blood obtained from the femoral artery.

\section{OBSERVATIONS}

The functional residual (subtidal) air was increased 18 hours after thoracentesis in 5 of the 6 patients studied, the increases ranging between 120 and $660 \mathrm{cc}$., or 5 and 31 per cent; the sixth patient showed an insignificant decrease of 35 cc., or 2 per cent. The average increase for the whole group was 301 cc., or 14 per cent. In the 2 patients studied up to 5 weeks after thoracentesis, further increases in functional residual air occurred, so that the final values were 805 and 1010 cc., or 38 and 40 per cent greater than the initial values (Table I).

The residual air increased in 3 patients, 18 hours after thoracentesis, by 245 to $450 \mathrm{cc}$., or 17 to 20 per cent. There was no change in one and insignificant decreases of 135 and $150 \mathrm{cc}$., or 8 and 10 per cent, in 2 patients. The average change for the whole group was an increase of 125 cc., or 6 per cent. There was no further increase in residual air in the 2 patients studied up to 5 weeks later.

The reserve (supplemental) air was greater after thoracentesis in every instance, the increase ranging between 100 and $320 \mathrm{cc}$., or 17 and 267 per cent of the initial value. The average increase was 176 cc., or 95 per cent. In the 2 patients studied up to 5 weeks later, the reserve air was further increased, so that the final values were 710 and 480 cc., or 592 and 400 per cent greater than the initial values. 
TABLE I

Lung volumes and pulmonary dynamics before and after thoracentesis

\begin{tabular}{|c|c|c|c|c|c|c|c|c|c|c|}
\hline Case & $\begin{array}{l}\text { Functional } \\
\text { residual air }\end{array}$ & $\begin{array}{l}\text { Residual } \\
\text { air }\end{array}$ & $\begin{array}{c}\text { Reserve } \\
\text { air }\end{array}$ & $\begin{array}{c}\text { Comple- } \\
\text { mental air }\end{array}$ & $\begin{array}{c}\text { Vital } \\
\text { capacity }\end{array}$ & $\begin{array}{c}\text { Total } \\
\text { capacity }\end{array}$ & $\begin{array}{l}\text { Respira- } \\
\text { tory rate }\end{array}$ & $\begin{array}{l}\text { Tidal } \\
\text { air }\end{array}$ & $\begin{array}{l}\text { Respira- } \\
\text { tory } \\
\text { volume }\end{array}$ & Remarks \\
\hline 1 & $\begin{array}{c}c c . \\
2135 \\
2795 \\
3060 \\
3140\end{array}$ & $\begin{array}{c}c c . \\
2015 \\
2355 \\
2310 \\
2310\end{array}$ & $\begin{array}{l}c c . \\
120 \\
440 \\
750 \\
830\end{array}$ & $\begin{array}{c}c c . \\
1190 \\
990 \\
1670 \\
1870\end{array}$ & $\begin{array}{c}c c . \\
1310 \\
1430 \\
2420 \\
2700\end{array}$ & $\begin{array}{c}c c . \\
3325 \\
3785 \\
4730 \\
5010\end{array}$ & $\begin{array}{c}\text { per minute } \\
24 \\
25 \\
19 \\
20\end{array}$ & $\begin{array}{l}c c . \\
505 \\
475 \\
475 \\
435\end{array}$ & 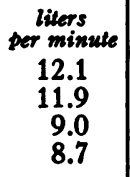 & $\begin{array}{l}\text { Before taps } \\
\text { After taps-3400 cc. } \\
\text { Two weeks after taps } \\
\text { Five weeks after taps }\end{array}$ \\
\hline 2 & $\begin{array}{l}2500 \\
3070 \\
3510\end{array}$ & $\begin{array}{l}2380 \\
2830 \\
2910\end{array}$ & $\begin{array}{l}120 \\
240 \\
600\end{array}$ & $\begin{array}{r}870 \\
850 \\
1860\end{array}$ & $\begin{array}{r}990 \\
1090 \\
2460\end{array}$ & $\begin{array}{l}3370 \\
3920 \\
5370\end{array}$ & $\begin{array}{l}26 \\
30 \\
23\end{array}$ & $\begin{array}{l}435 \\
475 \\
495\end{array}$ & $\begin{array}{l}11.3 \\
14.3 \\
11.4\end{array}$ & $\begin{array}{l}\text { Before tap } \\
\text { After tap-1100 cc. } \\
\text { Four weeks after tap }\end{array}$ \\
\hline 3 & $\begin{array}{l}2200 \\
2325\end{array}$ & $\begin{array}{l}1545 \\
1395\end{array}$ & $\begin{array}{l}655 \\
930\end{array}$ & $\begin{array}{l}1210 \\
1190\end{array}$ & $\begin{array}{l}1865 \\
2120\end{array}$ & $\begin{array}{l}3410 \\
3515\end{array}$ & $\begin{array}{l}23 \\
20\end{array}$ & $\begin{array}{l}360 \\
435\end{array}$ & $\begin{array}{l}8.3 \\
8.7\end{array}$ & $\begin{array}{l}\text { Before tap } \\
\text { After tap-1200 cc. }\end{array}$ \\
\hline 4 & $\begin{array}{l}1725 \\
1690\end{array}$ & $\begin{array}{l}1645 \\
1510\end{array}$ & $\begin{array}{r}80 \\
180\end{array}$ & $\begin{array}{l}1270 \\
1350\end{array}$ & $\begin{array}{l}1350 \\
1530\end{array}$ & $\begin{array}{l}2995 \\
3040\end{array}$ & $\begin{array}{l}20 \\
16\end{array}$ & $\begin{array}{l}515 \\
560\end{array}$ & $\begin{array}{r}10.3 \\
9.0\end{array}$ & $\begin{array}{l}\text { Before tap } \\
\text { After tap-1200 cc. }\end{array}$ \\
\hline 5 & $\begin{array}{l}2555 \\
2675\end{array}$ & $\begin{array}{l}1860 \\
1860\end{array}$ & $\begin{array}{l}695 \\
815\end{array}$ & $\begin{array}{l}1530 \\
1745\end{array}$ & $\begin{array}{l}2225 \\
2560\end{array}$ & $\begin{array}{l}4085 \\
4420\end{array}$ & $\begin{array}{l}21 \\
18\end{array}$ & $\begin{array}{l}360 \\
370\end{array}$ & $\begin{array}{l}7.5 \\
6.6\end{array}$ & $\begin{array}{l}\text { Before tap } \\
\text { After tap-1000 cc. }\end{array}$ \\
\hline 6 & $\begin{array}{l}1835 \\
2200\end{array}$ & $\begin{array}{l}1240 \\
1485\end{array}$ & $\begin{array}{l}595 \\
715\end{array}$ & $\begin{array}{l}1505 \\
1530\end{array}$ & $\begin{array}{l}2100 \\
2245\end{array}$ & $\begin{array}{l}3340 \\
3730\end{array}$ & $\begin{array}{l}34 \\
25\end{array}$ & $\begin{array}{l}335 \\
435\end{array}$ & $\begin{array}{l}11.4 \\
10.9\end{array}$ & $\begin{array}{l}\text { Before tap } \\
\text { After tap-700 cc. }\end{array}$ \\
\hline
\end{tabular}

The complemental air showed no constant or significant changes 18 hours after thoracentesis. There were increases of 25 to $215 \mathrm{cc}$. in 3 subjects and decreases of 20 to $200 \mathrm{cc}$. in the other 3; the range of percentage change was from plus 14 per cent to minus 17 per cent of the initial values. The average change was an increase of $13 \mathrm{cc}$., or one per cent. In the 2 patients studied up to 5 weeks later, the complemental air increased, so that the final values were 680 and $990 \mathrm{cc}$., or 57 and 114 per cent greater than the initial values.

The vital capacity increased somewhat, 18 hours after tapping. The increases ranged between 100 and $335 \mathrm{cc}$., or 7 and 15 per cent of the initial value; the average change was 189 cc., or 11 per cent. The increase after thoracentesis in each case was remarkably small compared to the volume of fluid removed. In the 2 patients studied up to 5 weeks later, further increases occurred, so that the final volumes were 1390 and 1470 cc., or 106 and 148 per cent greater than the initial values (Figure 1).

The total capacity increased somewhat, 18 hours after tapping. The increases ranged between 45 and $550 \mathrm{cc}$., or 2 and 16 per cent; the average increase was $314 \mathrm{cc}$., or 8 per cent. The change consequent to thoracentesis was small compared to the volume of fluid removed. In the 2 patients studied up to 5 weeks later, further increases occurred, so that the final volumes were 1685 and 2000 cc., or 51 and 59 per cent greater than the initial values.

TABLE II

Venous pressure and circulation time, before and after thoracentesis

\begin{tabular}{|c|c|c|c|}
\hline Case & $\begin{array}{l}\text { Venous } \\
\text { pressure }\end{array}$ & $\begin{array}{c}\text { Circulation } \\
\text { time }\end{array}$ & Remarks \\
\hline 1 & $\begin{array}{c}\mathrm{cm} . \mathrm{H}_{2} \mathrm{O} \\
9.2 \\
4.1 \\
3.7 \\
4.0\end{array}$ & $\begin{array}{c}\text { seconds } \\
14.6 \\
15.0 \\
16.1 \\
16.5\end{array}$ & $\begin{array}{l}\text { Before tap } \\
\text { After taps totaling } 3400 \mathrm{cc} \text {. } \\
\text { Two weeks after taps } \\
\text { Five weeks after taps }\end{array}$ \\
\hline 2 & $\begin{array}{r}10.0 \\
10.5 \\
0.0\end{array}$ & $\begin{array}{l}16.0 \\
16.5 \\
19.6\end{array}$ & $\begin{array}{l}\text { Before tap } \\
\text { After tap-1100 cc. } \\
\text { Four weeks later }\end{array}$ \\
\hline 3 & $\begin{array}{l}7.9 \\
4.8\end{array}$ & $\begin{array}{l}12.9 \\
13.6\end{array}$ & $\begin{array}{l}\text { Before tap } \\
\text { After tap-1200 cc. }\end{array}$ \\
\hline 4 & $\begin{array}{l}9.9 \\
7.6\end{array}$ & $\begin{array}{l}15.4 \\
13.7\end{array}$ & $\begin{array}{l}\text { Before tap } \\
\text { After tap-1200 cc. }\end{array}$ \\
\hline 5 & $\begin{array}{l}9.5 \\
6.4\end{array}$ & $\begin{array}{l}26.9 \\
25.7\end{array}$ & $\begin{array}{l}\text { Before tap } \\
\text { After tap-1000 cc. }\end{array}$ \\
\hline 6 & $\begin{array}{r}14.6 \\
9.1\end{array}$ & $\begin{array}{l}14.0 \\
15.0\end{array}$ & $\begin{array}{l}\text { Before tap } \\
\text { After tap-700 cc. }\end{array}$ \\
\hline 7 & $\begin{array}{r}12.8 \\
7.4\end{array}$ & $\begin{array}{l}24.6 \\
23.0\end{array}$ & $\begin{array}{l}\text { Before tap } \\
\text { After tap-1300 cc. }\end{array}$ \\
\hline 8 & $\begin{array}{l}16.5 \\
11.1\end{array}$ & $\begin{array}{l}41.4 \\
35.0\end{array}$ & $\begin{array}{l}\text { Before tap } \\
\text { After tap-2000 cc. }\end{array}$ \\
\hline
\end{tabular}




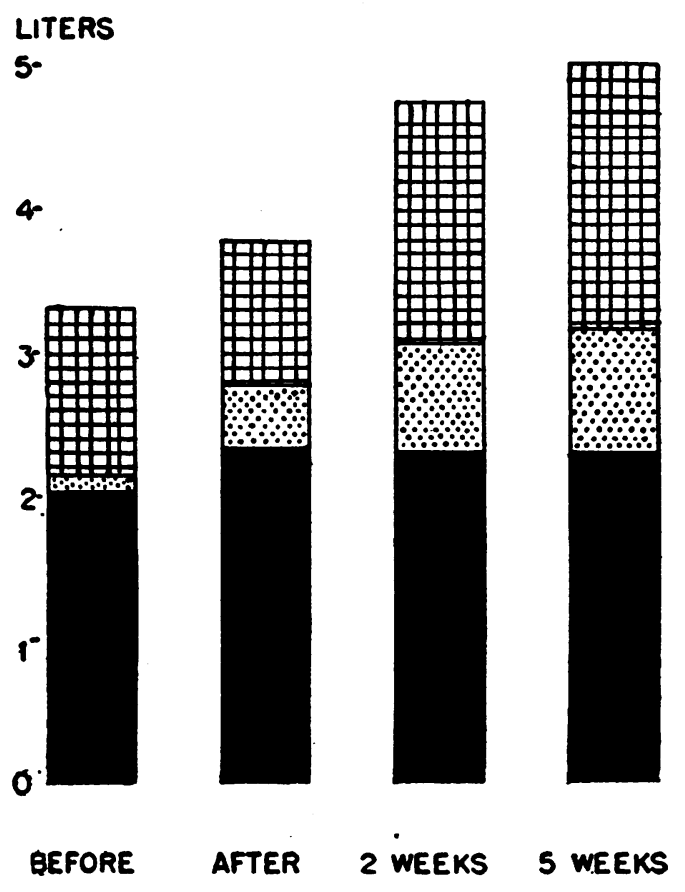

Fig. 1. Subdivisions of the Lung Volume in Patient 1 Before and After Thoracentesis

The respiratory dynamics showed no consistent changes, 18 hours after thoracentesis. The respiratory rate, high before tapping in all

TABLE III

Cardiac output before and after thoracentesis

\begin{tabular}{c|c|c|c|l}
\hline \hline Case & $\begin{array}{c}\text { Cardiac } \\
\text { output }\end{array}$ & $\begin{array}{c}\text { Cardiac } \\
\text { output }\end{array}$ & $\begin{array}{c}\text { Arterio- } \\
\text { venous } \\
\text { oxygen } \\
\text { difference }\end{array}$ & \multicolumn{1}{|c}{ Remarks } \\
\hline & $\begin{array}{c}L . \text { per } \\
\text { minute }\end{array}$ & $\begin{array}{c}L . \text { per } \\
100 \text { cc. } \\
\text { Oz con- } \\
\text { sumed } \\
3\end{array}$ & $\begin{array}{c}\text { oolumes } \\
\text { per cent }\end{array}$ & \\
& 3.83 & 1.79 & 5.58 & Before tap \\
& 3.96 & 1.92 & 5.20 & After tap-1200 cc. \\
\hline 5 & 2.66 & 1.08 & 9.24 & Before tap \\
& 2.70 & 1.05 & 9.52 & After tap-1000 cc. \\
\hline
\end{tabular}

TABLE IV

Arterial blood gases before and after thoracentesis

\begin{tabular}{|c|c|c|c|}
\hline Case & $\begin{array}{c}\text { Oxygen } \\
\text { saturation }\end{array}$ & $\begin{array}{c}\mathrm{CO}^{2} \\
\text { content }\end{array}$ & Remarks \\
\hline 5 & $\begin{array}{l}\text { per cent } \\
93.9 \\
93.1\end{array}$ & \begin{tabular}{|c} 
volumes per cent \\
47.02 \\
48.90
\end{tabular} & $\begin{array}{l}\text { Before tap } \\
\text { After tap-1000 cc. }\end{array}$ \\
\hline 7 & $\begin{array}{l}95.7 \\
96.9\end{array}$ & $\begin{array}{l}42.55 \\
42.43\end{array}$ & $\begin{array}{l}\text { Before tap } \\
\text { After tap-1300 cc. }\end{array}$ \\
\hline 8 & $\begin{array}{l}88.1 \\
92.2\end{array}$ & $\begin{array}{l}45.03 \\
46.22\end{array}$ & $\begin{array}{l}\text { Before tap } \\
\text { After tap-2000 cc. }\end{array}$ \\
\hline
\end{tabular}

patients, fell in only 4. The average tidal air volume was slightly to moderately increased after thoracentesis in 5 of the 6 patients. The respiratory minute volume showed no significant change.

The venous pressure, although within normal limits before thoracentesis in 5 of the 8 patients studied, fell immediately in all but one; the decreases ranged between 2.3 and $5.5 \mathrm{~cm}$. of water. In the eighth patient, a subsequent decrease of $10 \mathrm{~cm}$. occurred (Table II).

The circulation time and arterial blood pressure showed no consistent changes immediately after thoracentesis.

The pulse rate showed no significant change after thoracentesis; it varied from time to time in some of the patients, apparently in relation to changes in the degree of fever (Table III).

The cardiac output was studied in 2 patients, one (Patient 5) with congestive failure and the other (Patient 3) with no heart disease. The cardiac output before thoracentesis was low in the former and normal in the latter; there was no change 18 hours after tapping (Table IV).

The arterial blood gases were not remarkable before thoracentesis and were not influenced by removal of the pleural fluid in 2 of the 3 patients 
studied. In the third, the arterial oxygen saturation was 88.1 per cent before, and $\mathbf{9 2 . 2}$ per cent one hour after the chest tap.

\section{DISCUSSION}

Although many acceptable data on the vital capacity in patients with pleural effusion exist, reported observations ( 7 to 9 ) on the other subdivisions of the lung volume are fragmentary and were made by methods no longer considered reliable. In the present study, no analysis of the findings before thoracentesis was made, since most of the patients had some parenchymal disease in addition to the effusion. Significant changes were, however, found after thoracentesis in all the subdivisions of the lung volume except the residual and complemental airs; the changes in residual air may possibly be significant.

The functional residual air rose somewhat immediately after thoracentesis and therefore it is concluded that pleural effusion causes atelectasis, the collapsed lung re-expanding to some extent with removal of the thoracic fluid. Complete re-expansion, as measured by the functional residual air, did not, however, occur for 3 or 4 weeks. Accordingly, overcoming of the atelectasis must be regarded as only of contributory importance in the immediate relief of dyspnea which may occur with thoracentesis. Since the removal of large amounts of fluid from the chest is followed by an immediate increase in functional residual air of only a few hundred cubic centimeters, it is clear that elevation of the diaphragm must occur during thoracentesis. The diaphragm, pushed down and flattened by pleural effusion, resumes its normal arched contour as fluid is withdrawn. In its depressed, flattened state, the diaphragm is in a position which permits only limited excursion and makes for inefficient respiration; after resumption of its normal arch, diaphragmatic respiratory excursion is greatly increased and respiration becomes more efficient. This is in harmony with the clinical observation that patients with dyspnea associated with pleural effusion show active use of the accessory muscles of respiration which is abated by thoracentesis.

Of the two components of the functional residual air, i.e., the residual and reserve airs, the former is only slightly affected by pleural fluid, whereas the latter is markedly decreased. Other authors have pointed out that diminution in the volume of the reserve air in such diseases as emphysema (10) and congestive heart failure (11) is associated with decreased negativity of the intrapleural pressure; as the reserve air approaches zero, the intrapleural pressure approaches atmospheric. Accordingly, it is to be concluded from the data of the present study that the intrapleural pressure in patients with fluid in the pleural spaces is less negative than normal. Indeed, measurements of the intrapleural pressure in such patients have been recorded by Clark (12) and by Shattuck and Welles (13) and demonstrate the loss of all or most of the normal negative pressure. Following thoracentesis, the reserve air increases markedly and the intrapleural pressure has been shown to become more negative $(12,13)$. Decreased negativity of the intrapleural pressure, consequent to any cause, impairs the efficiency of respiration and also influences cardiovascular dynamics in a manner which will be discussed below.

The complemental air, a measure of the expansibility of the lungs, is markedly diminished by pleural fluid. This fluid acts to decrease pulmonary expansibility in two ways: (1) by occupying space within the thorax and (2) by causing atelectasis, the atelectatic lung being less expansible than the normal. Although the complemental air in the patients of the present study has never decreased to the volume of the resting tidal air, it was in some instances sufficiently small to prevent the normal increase in tidal air during exercise. Indeed, Knipping (14) found a decrease in maximal respiration during exertion in patients with pleural effusion. The decreased complemental air of pleural effusion therefore makes for anoxia during exertion and consequently contributes to dyspnea. Decreased arterial oxygen saturation was found in only one patient here studied at rest, but would probably occur in all during severe exertion. Ihaya (15) found lowered arterial blood oxygen saturation in most of his patients at rest. Impaired expansibility of the lungs also favors dyspnea by requiring that the patient expend more effort in attaining a given tidal air volume; in the present study, the tidal air volume was decreased 
before the removal of fluid. The complemental air is affected little by thoracentesis, attaining its normal volume only with complete re-expansion of the atelectatic lung in the weeks following removal of the fluid.

Early observers of the vital capacity noted $(16,17)$ that the vital capacity is low in patients with pleural effusion, but is only slightly increased immediately after thoracentesis; the findings of the present study are in harmony with these earlier observations. The vital capacity is the sum of the reserve and complemental airs; the latter is much larger than the former, so that its lack of change overshadows the marked changes in reserve air after pleural fluid is removed. The vital capacity returns to normal with the complemental air some weeks after chest tap. It is clear that study of the vital capacity in patients with pleural effusion affords no accurate information on the state of pulmonary function.

The total lung volume is decreased by pleural effusion and increases only slightly after thoracentesis, reaching normal levels several weeks later.

The above-discussed changes in intrapleural pressure in patients with pleural effusion impair venous return, as other authors pointed out $(18,19)$. In the present study, although the venous pressure was not elevated above normal in the patients without congestive failure, it fell following thoracentesis; this finding corroborates earlier observations by others $(12,26)$. The finding of Hitzig (20) that the venous pressure is within normal limits in patients with pleural effusion is not to be considered contradictory, since he did not study his patients before and after tapping. The fall in venous pressure which occurs after thoracentesis is of particular interest in that it may explain the occurrence of diuresis in some cardiac patients following this procedure. Impairment of venous return may result in decreased cardiac output. However, Ringer and Altschule (21), using the Henderson-Haggard ethyl iodide method, obtained values normal for that method in patients with pleural effusion, and Ihaya (15), who used the acetylene method, also found no striking deviation from normal. In the 2 patients studied here by the Starr and Gamble ethyl iodide method, a normal cardiac output was found in the one with no heart disease and decreased values in the patient with congestive heart failure, with no change in the output of the heart in either after tapping. Busacchi (22), using the acetylene method, found markedly decreased cardiac outputs in most of his patients with pleural effusion, with return to normal following clearing of the fluid. His observations, however, are not entirely applicable to the present discussion, since at least some of his patients had adhesive mediastino-pericarditis. Moreover, his data on normal subjects are so variable as to suggest some error in procedure. It is therefore concluded that pleural effusion does not affect the cardiac output in patients at rest. This is in harmony with the observations on decholin circulation time reported here and on saccharine and ether times recorded earlier by Hitzig (20). Although some obstruction to the return of blood from the periphery exists because of decreased negativity of intrapleural pressure, it appears that enough pressure is built up in the veins so that flow is not decreased and therefore cardiac output remains unchanged in these patients at rest. It is probable, however, that the increase in cardiac output in exercise in patients with hydrothorax would be less than normal. Evidences of impaired cardiac function, consequent to extreme degrees of pressure on the heart or of mediastinal displacement, were not observed in the present study, but this does not rule out their occurrence in patients with larger amounts of fluid in the pleural spaces.

It is clear from all of the above discussion that pleural effusion acts in many ways to impair respiratory and cardiac function. Nevertheless, many patients with large effusions exhibit little or no discomfort, at least while at rest. The results of the present study show that the changes in pulmonary physiology caused by hydrothorax are similar to those consequent to emphysema $(11,23)$, diffuse pulmonary fibrosis (24), and chronic congestive failure $(10,25)$. Accordingly, patients with diffuse pulmonary disease, i.e., emphysema, fibrosis, or congestion, are more likely to exhibit dyspnea and orthopnea when pleural fluid develops than other patients. The severity of these respiratory symptoms varies, not only with the volume of fluid in the 


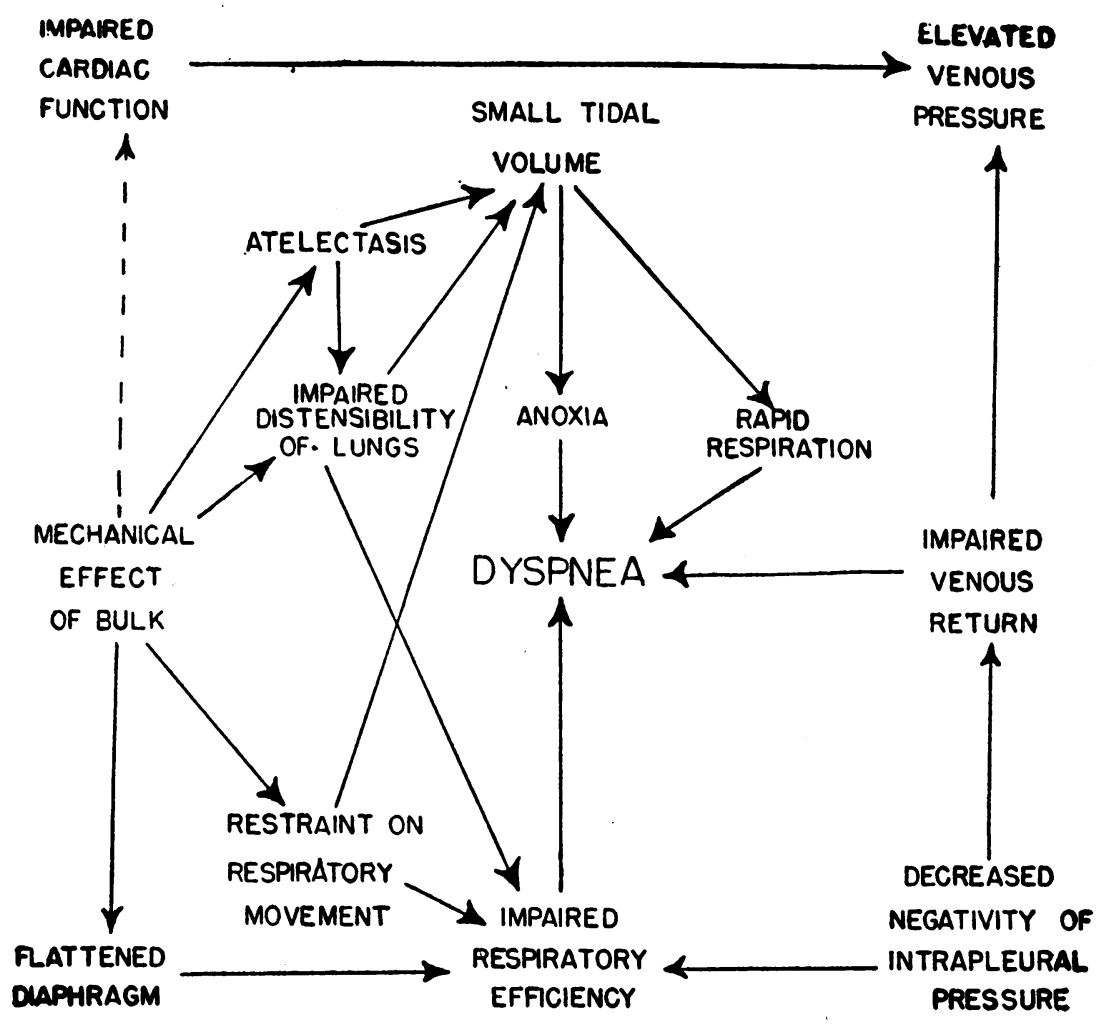

Fig. 2. Some Mechanisms Favoring Dyspnea in Patients with Pleural Effusion

pleural spaces, but also with the severity of the underlying pulmonary disease. Conversely, if a patient obtains marked relief from respiratory discomfort following a relatively small thoracentesis, it is likely that he also has some diffuse pulmonary lesion (Figure 2).

The effects of thoracentesis may be summarized as follows:

\section{A. Immediate}

1. Increased negativity of intrapleural pressure

a. improved respiratory efficiency

b. improved venous return

2. Removal of bulk of fluid

a. removal of restraint on respiration

b. restoration of diaphragmatic arch

3. Some re-expansion of collapsed lung

\section{B. Late}

1. Re-expansion of atelectasis

a. increased respiratory space

b. restoration of expansibility of lung

\section{SUMMARY AND CONCLUSIONS}

1. The effects of pleural effusion have been estimated in 8 patients by comparison of measurements of the lung volume and respiratory and cardiovascular dynamics before and after thoracentesis.

2. Atelectasis, decreased expansibility of the lungs, decreased negativity of intrapleural pressure, and shallow respiration are consequences of pleural effusion; anoxia may occur.

3. Increased peripheral venous pressure, a manifestation of impaired venous return consequent to changes in intrapleural pressure, is caused by pleural effusion. There are no changes in cardiac output or circulation time, at least at rest, as a consequence of pleural fluid.

4. It is concluded that pleural effusion impairs respiration and circulation in many ways, thereby favoring the occurrence of dyspnea and orthopnea; these symptoms will be most severe in patients who have extensive diffuse disease of the lungs in addition to the effusion. 


\section{BIBLIOGRAPHY}

1. Starr, I., Jr., and Gamble, C. J., An improved method for the determination of cardiac output in man by means of ethyl iodide. Am. J. Physiol., 1928, 87, 450.

2. Christie, R. V., The lung volume and its subdivisions. I. Methods of measurement. J. Clin. Invest., 1932, 11, 1099.

3. Iglauer, A., and Altschule, M. D., The effect of arterial and venous constriction induced by paredrine (p-hydroxy-a-methylphenylethylamine hydrobromide) on the lung capacity and its subdivisions. Am. J. M. Sc., 1941, 201, 664.

4. Moritz, F., and von Tabora, D., Ueber eine Methode, beim Menschen den Druck in oberflächlichen Venen exakt zu bestimmen. Deutsch. Arch. f. klin. Med., 1910, 98, 475.

5. Winternitz, M., Deutsch, J., and Brüll, Z., Eine klinischbrauchbare Bestimmungsmethode der Blutumlaufzeit mittels Decholininjektion. Med. Klin., 1931, 27, 986.

6. Van Slyke, D. D., and Neill, J. M., The determination of gases in blood and other solutions by vacuum extraction and manometric measurement. I. J. Biol. Chem., 1924, 61, 523.

7. Bittorf, A., and Forschbach, J., Untersuchungen ueber die Lungenfuellung bei Krankheiten. Ztschr. $f$. klin. Med., 1910, 70, 474.

8. Plesch, J., Die pathologische Physiologie des Lungenvolumens und seine Beziehung zum Kreislauf. Ztschr. f. expt. Path. u. Therap., 1913, 13, 165.

9. Peters, J. P., Jr., and Barr, D. P., Studies of the respiratory mechanism in cardiac dyspnea. II. A note on the effective lung volume in cardiac dyspnea. Am. J. Physiol., 1920, 54, 335.

10. Christie, R. V., and Meakins, J. C., The intrapleural pressure in congestive heart failure and its clinical significance. J. Clin. Invest. 1934, 13, 323.

11. Christie, R. V., The elastic properties of the emphysematous lung and their clinical significance. $\mathrm{J}$. Clin. Invest. 1934, 13, 295.

12. Clark, A. H., A study of the diagnostic and prognostic significance of venous pressure observations in cardiac disease. Arch. Int. Med., 1915, 16, 587.

13. Shattuck, G. C., and Welles, E. S., Intrathoracic pressure in haemothorax, pneumothorax and pleural effusion and effects of aspiration and of oxygen replacement. Quart. J. Med., 1919, 12, 151.

14. Knipping, H.W., Ueber die respiratorische Insufficienz. Klin. Wchnschr., 1935, 14, 406.

15. Ihaya, H., Studien ueber die Alveolarluft, Blutgase, Vitalkapazitaet und Minuten- und Schlagvolumen des Herzens bei Beriberi, Herzklappenfehler und Pleuritis. Mitt. d. med. Gesellsch. zu Tokio, 1934, 48, 2167.

16. Peabody, F. W., and Wentworth, J. A., Clinical studies of the respiration. IV. The vital capacity of the lungs and its relation to dyspnea. Arch. Int. Med., $1917,20,443$.

17. Graham, E. A., The importance of the vital capacity in thoracic surgery. J.A.M.A., 1920, 75, 992.

18. Hooker, D. R., Observations on the venous blood pressure in man. Am. J. Physiol., 1914, 35, 73.

19. Kroetz, C., Die Koeffizienten des klinisch messbaren Venendruckes. Deutsch. Arch. f. klin. Med., 1922, 139, 325.

20. Hitzig, W. H., The use of ether in measuring the circulation time from the antecubital veins to the pulmonary capillaries. Am. Heart J., 1935, 10, 1080.

21. Ringer, M., and Altschule, M.D., Studies on the circulation. II. Cardiac output in diseases of the heart, and under the influence of digitalis therapy. Am. Heart J., 1930, 5, 305.

22. Busacchi, V., La portata circulatoria e la gittata sistolica in condizioni normali e patologiche. Nota terza. Pleuritici. Arch. di Pat. e. Clin. Med., 1938, 18, 140.

23. Hurtado, A., et al., Studies of total pulmonary capacity and its subdivisions. VI. Observations on cases of obstructive pulmonary emphysema. J. Clin. Invest., 1934, 13, 1027.

24. Hurtado, A., et al., Studies of total pulmonary capacity and its subdivisions. VIII. Observations on cases of pulmonary fibrosis. J. Clin. Invest., 1935, 14, 81.

25. Altschule, M. D., Zamcheck, N., and Iglauer, A., The lung volume and its subdivisions in the upright and recumbent positions in patients with congestive failure. Pulmonary factors in the genesis of orthopnea. J. Clin. Invest., 1943, 22, 805.

26. Taylor, F. A., Thomas, A. B., and Schleiter, H. G., A direct method for the estimation of venous blood pressure. Proc. Soc. Exper. Biol. and Med., 1930, 27,867 . 